\title{
Glossary: unemployment, job insecurity, and health
}

\author{
M Bartley, J Ferrie
}

\section{Unemployment, job insecurity, and health: key concepts}

Writing a glossary on unemployment and health for an international epidemiological journal poses a number of rather daunting challenges. However, these are the sorts of challenges we need to accept in order to further the understanding of social factors in health and disease. First of all, every nation has its own ways of defining unemployment and administering benefits. Even the ideas of "unemployment" and "benefits" are less salient in many nations. The exchange of labour for money is by no means the only form of productive activity, and family and community structure form the major source of support for those not engaged in such activity in many areas of the world. In both writing and reading this glossary therefore, it is necessary to bear in mind that it deals with unemployment and health. We have confined our entries to those we felt most relevant to understanding the existing literature on this topic. We have not set out (nor could we) to write a comprehensive glossary on unemployment and benefits: there are several books that aim to do this, with varying degrees of completeness, and some of these are included in our references.

The 1990s in many developed countries saw national commitments to security of employment abandoned in favour of labour market flexibility, accompanied by large increases in part time and temporary work, self employment and fixed term contracts, as organisations in the public and private sector engaged in restructuring and downsizing. For the individual employee the corollary of labour market flexibility is job insecurity. The possible health effects of these organisational changes are becoming a lively new area of research. We therefore include some terms that are used to describe these processes.

The glossary is not merely descriptive, but is informed by a certain general approach. This is that the investigation of the relation between unemployment and health needs to take place against the wider background of health inequality. Spells of unemployment, job insecurity, and economic inactivity do not fall randomly in working populations, but tend to cluster. Less secure jobs also tend to entail higher levels of exposure to other hazards such as dangerous substances and working conditions, as well as lower pay. Over the life course, then, someone who is at risk of unemployment will also be at increased risk of health damaging conditions.

We have included consideration of EspingAndersen's concept of commodification for two reasons. Firstly, because it was developed as part of an international comparative study of welfare, and we hope that this glossary may contribute to more international comparative studies of unemployment, job insecurity and health. Secondly, because it offers a conceptual framework that may be a useful starting point for such international studies. It leads us to ask a set of questions of different social arrangements such as: what are the major sources of financial support for the unemployed? How do benefit levels compare to the average wage, or to the lowest quintile or decile? What are the arrangements for re-training and rehabilitation? What proportion of the working population is protected by job security laws, and how is this changing over time? Differences in these respects influence both the experience of unemployment and also the composition of both the employed and unemployed population in ways that are of epidemiological significance. $^{1}$

\section{Glossary of terms}

a indicates words included in a definition that are themselves defined elsewhere in the glossary.

Active labour market policies: are pursued in some European nations to try and avoid long term unemployment and work disability. The presence of these policies can make the active labour force less selected for good health (selection of the active labour force

Benefit: in most industrial countries, some or all unemployed citizens are eligible for some kind of financial support (contributory unemployment benefit non-contributory benefit are, social assistance social insurance Eligibility for these benefits, and the amount, vary very widely.

Claimant count: a way to measure unemployment by counting up the numbers of people who are claiming unemployment benefit. The inadequacy of this measure is that by no means everyone who needs a job claims benefit 
Commodification of labour power: a concept introduced by Esping-Andersen in his influential comparative study of welfare systems. ${ }^{2}$ It refers to the degree to which living standards are protected while a person is unable to work. The idea is that the more strictly labour is treated as a "commodity", the less will be paid to those unable to "sell" it (by being employed). If labour is a true commodity, it only has value when it is in demand by employers for productive activity, not when a person is unemployed, ill, or working only in the home or voluntarily in the community. Most modern nations do not allow those without work literally to starve when not employed. There will however be a gap between the level of benefits for those not in work and the average wage. This is a major factor in assessing the "degree of commodification" in any country. The concept has obvious relevance for the study of social determinants of health. ${ }^{34}$

Contributory unemployment benefit: the type of social insurance benefit that depends on contributions made while in work. These are only available to people who have paid ("contributed") a certain amount during a period when they were employed. This type of benefit can be received regardless of other resources when the person becomes unemployed (it is not means tested However, under most schemes, it can only be claimed for a limited time. After this time has passed, the person is said to have "exhausted their right to benefit". Those who only work intermittently and change jobs often are at risk of never being eligible for contributory benefits. As any spell of unemployment is highly predictive of future spells, a high proportion of all unemployed people at any one time will therefore depend on non-contributory or social assistance benefits. ${ }^{56}$

Cross sectional studies: early evidence on the link between unemployment and health often came from comparisons of the employed and unemployed at the same time. These always found large health differences. However they were criticised on the grounds that the unemployed may have been selected (see health selection because they were in poor health. ${ }^{7}$

Demand for labour: the number of jobs in the economy of a given nation. Most demand is for a specific skill level. In the 1980s, the demand for both more and less skilled industrial labour decreased sharply in developed nations as technology advanced. ${ }^{8}$ In the $2000 \mathrm{~s}$ it is predicted that the demand for many types of skilled non-manual labour (clerical, secretarial, data processing) will also decline. The demand for unskilled non-industrial labour (such as that required in catering, care homes, and private domestic service), however, will increase. ${ }^{9}$ "Demand-side economic policies" are the Keynesian ones, which attempt to increase the numbers of jobs by government financed schemes (that is, by increasing the demand for labour, especially less skilled labour).

Downsizing: is the name given to the process whereby an organisation reduces its work force through natural wastage or redundancy many euphemisms, such as restructuring, retrenching, rightsizing, skill mix adjustment, of which downsizing has become the term most widely used.

Early retirement: The definition of early retirement used generally in government information to older people is "retirement before state pensionable age". ${ }^{10}$ Some of those who take early retirement actively seek further employment, but many leave the labour force for good, either through ill health or by choice. Thus, the social meaning of early retirement and redundancy are not fixed but dependent on the prevailing level of unemployment and the financial implications of the different ways of leaving employment. ${ }^{11}$ In response to changes in public policy, early retirement, in most industrialised countries, rose considerably during the 1980s and most of the 1990s. However, recent policy changes are aimed at stemming this out flow of older workers from the labour market

Economically active: a person, at or above the minimum age for full time employment and below the state retirement age, who is either employed or looking for work.

Economically inactive: a person, at or above the minimum age for full time employment and below the state retirement age, who is not employed or looking for work. Economic inactivity is usually due to long term ill health. However, economically inactive is also used to describe those doing full time unpaid domestic work, early retirees, and a small group of persons of private means who do not want to work.

Employment security: while job security represents the ability to remain in a particular job, employment security represents the likelihood of being able to remain in paid employment, even if this is a succession of jobs.

Factory (and workplace) closures: were considered to provide good natural experiments for the study of unemployment and health because, in theory, there should be no selection. Health and other possible confounders of the relation should not influence the occurrence of unemployment under these circumstances. Although factory closure studies form a relatively small proportion of the extensive literature on unemployment and health, this unique feature has enabled them to make a significant contribution to knowledge about the effect of unemployment on the health of individuals. ${ }^{12}$ They also help bridge the gap between case history accounts of the health effects of employment status on one hand and macrostatistical studies of total populations, correlating economic data and health indices, on the other. ${ }^{13}$

The absence of selection in factory closure studies has been questioned by some researchers. ${ }^{14}$ It may be that workers are aware of impending closure long before it happens, and the more vigourous members of the workforce leave as soon as rumours begin. This gives them the great advantage of looking for work in a labour market that is not already flooded by a mass redundancy ${ }^{15}$ 
Flexible labour market: is one in which employees are no longer expected to deliver competence in a single job, but to possess multiple generic skills adaptable to changing employer(s) demands.

Full employment: according to Sinfield, a full or social definition of full employment never seems to have been spelt out. ${ }^{5}$ He claims that there has been little debate about the concept since it was defined by Beveridge:

"[full employment] means always having more vacant jobs than unemployed men, not slightly fewer jobs. It means the jobs are at fair wages, of such a kind, and so located that the unemployed men can reasonably be expected to take them; it means, by consequence, that the normal lag between losing one job and finding another will be very short." (Beveridge WH. Full employment in a free society. Allen and Unwin, 1944 (quoted in Sinfield $\left.)^{5}\right)$.

Health selection-direct: the idea that people come to be unemployed, or remain unemployed, because of a disease. At one time this was a popular theory to explain the relation of unemployment to ill health and mortality. No longer believed because of work on the wearing off of selection

Health selection-indirect: the theory that people come to be unemployed because of a factor that also makes them more susceptible to illness or mortality. ${ }^{16}{ }^{17}$ What the factor might be is seldom spelt out in exact terms. Candidates include depression or other psychological traits, such a low intelligence, or a set of attitudes such as fatalism. There is evidence that people with more materially and psychologically disadvantaged life histories are at greater risk of unemployment ${ }^{18}$

Hive off: the transfer of profitable activities of a nationalised industry back to private ownership (see privatisation ${ }^{19}$

International Labour Organisation (ILO) definition of unemployment: all persons above the specified age (for each nation) who during the reference period were not in paid employment or self employment, were available for paid employment or self employment and had taken specific steps in a specified recent period (varies between countries) to seek paid or self employment. These steps may include registration at a public or private employment exchange; applying for jobs; checking at work sites; advertising for work; seeking help from friends or relatives to find work; looking for resources to start one's own business or arranging to borrow money to start one's own business. These criteria are relaxed where the labour market is "largely unorganised" or where for other reasons they are obviously inappropriate. The ILO recommend that appropriate tests for national circumstances be developed. These criteria could include a desire to work or a readiness to take up self employment given the local circumstances. ${ }^{20}$

This definition does not depend on whether or not a person actually receives benefits so it includes spouses of employed people, and younger people who are not eligible for benefit. However, it is widely regarded somewhat limited by the concept of "taking steps". Despite the wide and flexible definition of "taking action to find work or self employment" there may still be many people who would like to work but take no actions to find work because they believe they would not succeed.

Fob insecurity: much work on the concept of job insecurity has been carried out by Hartley and colleagues who define it, in general terms, as the discrepancy between the level of security a person experiences and the level she or he might prefer. ${ }^{21}$ Some researchers limit the concept of job insecurity to the threat of total job loss while others extend it to include loss of any valued condition of employment. ${ }^{22}$

The depth of the job insecurity experience will be dependent on the perceived probability and perceived severity of losing one's job. ${ }^{21}$ Thus, job insecurity has a large subjective appraisal element that will be highly context dependent, and the job insecurity experience may affect employees who, ultimately, are not made redundant as much as those who are. Job insecurity arising from the threat to a particular job may lead to loss of employment security if subsequent jobs prove hard to find.

fob insecurity studies: job insecurity can be self perceived or externally attributed. The population in studies of self perceived job insecurity is comprised of people who report their job as insecure. In studies of attributed job insecurity the study population is deemed to be under threat of job loss by the researchers. Associations observed in studies of attributed job insecurity are likely to be underestimates, as the study population will contain respondents who do not perceive themselves to be under threat. ${ }^{23}$

Labour force in employment: this is a measure obtained from household surveys and censuses that includes all employees, self employed persons, participants in government employment and training programmes, and persons doing unpaid family work. (page 72 ) $^{24}$

Labour force participation rate: defined as (employed + unemployed and actively seeking work)/all of working age.

Labour market: the place where the supply of labour meets the demand for labour Studies of unemployment and health benefit from an understanding of labour markets. For example, a common fallacy is to imagine that better health or greater qualification will automatically result in an individual gaining employment. In fact, there are often not a sufficient number of jobs for everyone who wants and needs to work. On the other hand, many of those who seem to be too sick to work at a time of low demand will find work when demand rises.

Longitudinal studies: these are preferred over cross sectional studies on the grounds that they may guard against selection biases. ${ }^{7}$ However, it is very difficult to be sure that some change in health may not have taken place in any time interval between measurements, which may account for higher rates of ill health in the unemployed. In addition, there may be unobserved factors (see health selection- 
indirect 5 ), which differentiate those who will later experience unemployment from those who will not.

Long term unemployment: unemployment of more than 12 months. ${ }^{25}$

Market testing: the process whereby employees (usually public sector) have to tender for their traditional domains of work against outside competition. This process may lead to the contracting out or privatisation of services.

Means test: benefits available to unemployed persons in most nations that have welfare provision for the unemployed are often subject to a "means test". That is, they are only paid to those with less than a certain amount of other income or savings available to the individual themselves, or often to their spouse or partner. Means testing is not usually applied to contributory benefits where benefit is paid in respect of social insurance contributions while in work. It is usually applied to "safety net" non-contributory or social assistance benefits. Thus, a person in a system that pays social insurance benefits to the unemployed for the first 12 months and social assistance benefits thereafter will find that after the year has passed, their savings and their spouse's income will be assessed before benefit is allowed to continue.

Michigan Study: was the first factory closure Te study. It provided many insights into working lives both in and out of employment. ${ }^{26}$

Natural wastage: occurs when employees who retire or choose to leave an organisation are not replaced.

Non-contributory benefit: the benefits available as a safety net to those who have not paid contributions to a social insurance scheme, or whose contributory benefits are insufficient or have run out. These are usually subject to a means test

Poverty trap: exists because the wage levels for many jobs are less than, or hardly more than, the sum of individual and family benefits are paid to adults when unemployed. An unemployed person may receive a personal allowance, another allowance for housing costs, allowances for each child or adult dependant and other free services such as school meals and dental treatment. When returning to work, the free services and allowances are often withdrawn, making the person hardly better off financially.

Precarious employment: is all employment that does not have a permanent contract. The main categories of workers in precarious employment are those with fixed term or temporary contracts, both full time and part time. ${ }^{27}$

Privatisation: the hiving off of the manufacture of goods or provision of services provided by the public sector. Such transfers of functions are usually described as "sales", although they frequently involve sweeteners being paid to the "purchaser", and guarantees of exclusive access to markets for a set period.

Psychological contract: refers to the worker's beliefs regarding the terms and conditions of her or his employment. Fairness and good faith are implied in the psychological contract and breaches have implications for the worker's trust in the organisation, performance and behaviour. $^{28}$

Redundancy: becoming unemployed due to insufficient work being available in one's place of employment. This type of unemployment is in theory not selective (see health selection ar) in that it is the failure of demand for labour that is responsible. However, at times when only part of the workforce is being made redundant, managers may choose those who have poorer health records or slight mental health or substance use problems. Trade union members and militants are also often targeted for redundancy. The "last in first out" rule says that the longest serving workers should be the last to be made redundant. This is one reason why those with recent spells of unemployment were more at risk of further spells. ${ }^{15}{ }^{29}$ However, this practice is no longer widespread.

Replacement ratio: is the ratio between the amount paid in benefit and the previous wage or salary. This varies enormously between countries. However, in countries with higher replacement ratios, the excess risk of mortality in longer term unemployed persons does not seem to be lower than it is in countries with lower ratios.

Secondary labour market: is that section of the labour market in which wages are low and employment rights few. Such employment is often seasonal, part time or temporary, and is frequently used to buffer short-term changes in labour requirements. This labour force is comprised mainly of foreign workers, immigrants, ethnic minorities, older workers, and to some extent women, especially those with young children. ${ }^{21}$

Selection of the active labour force: at times of high unemployment the active labour force will be more "selected for good health", 31 because employers are more able to pick and choose the healthiest workers. People who have any kind of long term illness find it harder to gain work. People over the age of 50, or even 45 , begin to be seen as too old to be hired. This has its greatest effect on those in manual occupations. ${ }^{32}$ Because manual occupations become more highly health selected at times of high unemployment, health differences between social classes may even seem to have disappeared. ${ }^{33}$ These effects of unemployment trends make it important to record the last held occupation when studying health inequality during periods of economic change. (For health selection of individuals see health selection direct and indirect

Social assistance: the term used to refer to non-contributory benefit. This is the "safety net", which does not exist in some countries. This form of benefit is financed by central taxation and does not depend on contributions. It is almost always means tested

Social class of the unemployed: the social classification of the unemployed is problematic as most systems, such as the registrar general's social class - the most frequently used measure in the UK-are based on occupation. Thus the allocation of social class to unemployed 
persons is largely dependent on the data available and the purposes of the research. If a full employment history is available, the longest job held is probably the best indicator of socioeconomic position during adulthood. The "best" job ever held will give an inflated answer because of coding error, particularly if the unemployed person has held lots of jobs. If a reflection of a person's current situation is required the best indication might be their last job, as this is likely to take into account any downward drift into unemployment (Brendan Burchell, personal communication)

Social distribution of unemployment: unemployment is by no means randomly distributed in the economically active population. ${ }^{56}$ It is always more prevalent among less privileged social groups. Much routine manual work is inherently insecure, such as labouring on building sites, road construction, seasonal agricultural work, etc. Ethnic minority groups often have high unemployment risk because of discrimination by employers. Once a person has suffered a spell of unemployment, they are known to be at higher risk of a more insecure work history. A large proportion of all time spent in unemployment is experienced by a relatively small proportion of the working population, either as long term unemployment or as repeated spells. ${ }^{15} 3435$ The gender distribution of unemployment is rather difficult to assess. According to official figures for the late 1990 s, there are large national variations. In the UK the unemployment rate in women was under half that in men, in Norway and Finland rates were almost equal, while in Italy and Spain unemployment was up to twice as prevalent in women as in men.

Social insurance: one form taken by unemployment benefits, the "contributory" form. Under social insurance, citizens pay a premium while they are in work, employers often also pay into the fund. This is used to finance benefit when out of work. Only those who are "paid up" are eligible for this type of benefit

Underemployment: used in general to describe a person who is in paid employment, who works at least one hour a week, but wants to do more paid work. The ILO definition, adopted in 1998, includes all those in employment who satisfy three criteria; that they want to work additional hours, were available to work additional hours, and already worked less than a threshold number of hours. ${ }^{36}$

Unemployment: the meaning of this term varies in each country. In the UK there have been many definitions, changed over time to suit the political purposes of governments. Some of the most common definitions are listed under separate headings. Roughly speaking the unemployment rate amounts to the proportion of all those of working age in a given area who do not have a job and are actively seeking one. It often leaves out large numbers of people who would like to work but are prevented even from looking for work, such as many people with long term illness who could work if working conditions were better, and parents who could work if child care services were adequate.

Wearing off of selection: a method that will help to test empirically whether an association between membership of a social group and mortality is causal. ${ }^{37-40}$ It can only be used with longitudinal data. The method is to see whether the strength of the association is weaker later on in any follow up period. If high mortality in a sociodemographic group (such as the unemployed) is attributable to the presence in that group of people who were going to die anyway because of some pre-existing illness, as the "ill" group die the association will weaken. Absence of wearing off shows that it is likely to be exposure to conditions in the sociodemographic group that continue to put members at high risk.

Work intensification: increased pressure at work from colleagues or work mates, managers or supervisors, and the sheer quantity of work. ${ }^{41}$

Workplace closure studies: see factory closure os studies

Funding: Mel Bartley is funded by Economic and Social Research Council Senior Fellowship number R000271112, and Jane Ferrie was supported by the Economic and Social Research Council (L128251046) during the preparation of this paper. Conflicts of interest: none.

1 Martikainen P, Valkonen, T. Bias related to the exclusion of the economically inactive in studies on social class

2 Esping-Andersen G. Three worlds of welfare capitalism. Cambridge: Polity Press, 1990

3 Bartley M. Health and labour force participation: stress, selection, and the reproduction costs of labour power. $\mathcal{F}$ Social Policy 1991;20:327-64

4 Bartley M, Blane D, Montgomery S. Health and the life course: why safety nets matter. BMF 1997;314:1194-6.

5 Sinfield A. What unemployment means. Oxford: Martin Robertson, 1981.

6 Stern J. Who bears the burden of unemployment? In: Beckermann W. Slow growth in Britain. Oxford: Clarendon, 1979

7 Platt S. Unemployment and suicidal behaviour: a review of the literature. Soc Sci Med 1984;19:93-115.

8 Nickell S, Bell B. The collapse in demand for the unskilled and unemployed across the OECD. Oxford Review of Economic Policy 1995;11:40-62.

9 Gregson N, Lowe M. Servicing the middle classes: class, gender and domestic labour in contemporary Britain. London: and domestic labour

10 Department of Social Security. Retiring? Your pension and other benefits. London: HMSO, 1990.

11 Johnson, P. The labour force participation of older men in Britain, 1951-81. Work, Employment and Society 1989;3: 351-68.

2 Kasl S. Strategies of research on economic instability and health. Psychol Med 1982;12:637-49.

13 Bartley M, Fagin L. Hospital admissions before and after shipyard closure. Br F Psychiatry 1990;156:421-4

4 Morris JK, Cook DG. A critical review of the effect of factory closures on health. Br F Ind Med 1991;48:1-8.

15 Westergaard J, Noble I, Walker A. After redundancy: the experience of economic insecurity. Cambridge: Polity Press, 1989.

16 Martikainen PT, Valkonen T. The effects of differential unemployment rate increases of occupation groups on unemployment rate increases of occupation groups on

17 Martikainen PT, Valkonen T. Excess mortality of unemployed men and women during a period of rapidly increasployed men and women during a period of rap

18 Montgomery SM, Bartley MJ, Cook DG, et al. Health and social precursors of unemployment in young men in Great Britain. F Epidemiol Community Health 1996;50:415-22.

19 Hanks P, ed. Collins dictionary of the English language Collins: London, 1979.

20 International Labour Office. A resolution concerning statistics of the economically active population, 13th International Conference of Labour Statistics, October 1982, http://www.ilo.org/public/english/bureau/stat/res/ ecacpop.htm

21 Hartley J, Jacobson D, Klandermans B, et al. Fob insecurity: coping with jobs at risk. London: Sage Publications, 1991.

22 Greenhalgh L, Rosenblatt Z. Job insecurity: Towards conceptual clarity. Academy of Management Review 1984;9: 438-48.

23 Ferrie JE. Is job insecurity harmful to health? $\mathcal{f} R$ Soc Med 2001;94:71-6. 
24 Social Trends 27. London: The Stationery Office, 1997.

5 Laczko F, Phillipson C. Changing work and retirement. Milton Keynes: Open University Press, 1991.

26 Cobb S, Kasl SV. Termination: the consequences of job loss. Cincinatti: DHEW-NIOSH Publication no 77-224, National Institutes for Occupational Safety and Health, 1977.

27 Benavides FG, Benach J. Precarious employment and health-related outcomes in the European Union. European Foundation for the Improvement of Living and Working Conditions. Luxembourg: Office for Official Publications of the European Communities, 1999.

28 Rosenblatt Z, Schaeffer Z. Ethical problems in downsizing. In: Burke RJ, Cooper CL, eds. The organisation in crisis: downsizing, restructuring and privatisation. Oxford: Blackwell, 2000:132-50.

29 Harris CC. Redundancy and recession. Oxford: Blackwell, 1987.

30 Fox AJ, Goldblatt PO. Longitudinal Study: Socio-demographic mortality differentials. London: HMSO, 1982.

31 Moser K, Goldblatt PO, Fox AJ, et al. Unemployment and Moser K, Goldblatt PO, Fox AJ,

32 Bartley M, Owen C. Relation between socioeconomic status, employment and health during a time of economic change 1973-1993. BMF 1996;313:445-8.
33 Lahelma E, Arber S, Rahkonen O, et al. Widening or narrowing inequalities in health? Comparing Britain and Finland from the 1980 s to the 1990 s. Sociol Health Illness 2000;22:110-36

34 White M. Against unemployment. London: PSI, 1991.

35 Daniel WW. The unemployed flow. London: PSI, 1990.

36 Bivand P. Measuring underemployment. Working Brief 1999;108:19-21.

37 Fox AJ, Goldblatt PO. Economic activity. Longitudinal Study: socio-demographic mortality differentials. London: HMSO, 1982:LS 1, 23-41.

38 Fox AJ, Goldblatt PO, Adelstein AM. Selection and mortality differentials. F Epidemiol Community Health 1982; 36:151.

39 Moser KA, Goldblatt PO, Fox AJ, et al. Unemployment and mortality - comparison of the 1971 and 1981 longitudinalstudy census samples. BMF 1987;294:86-90.

40 Fox AJ, Shewry M. New longitudinal insights into relationships between unemployment and mortality. Stress Med 1988;4:11-19.

41 Burchell B, Day D, Hudson M, et al. Fob insecurity and work intensification. York: Joseph Rowntree Foundation, 1999.

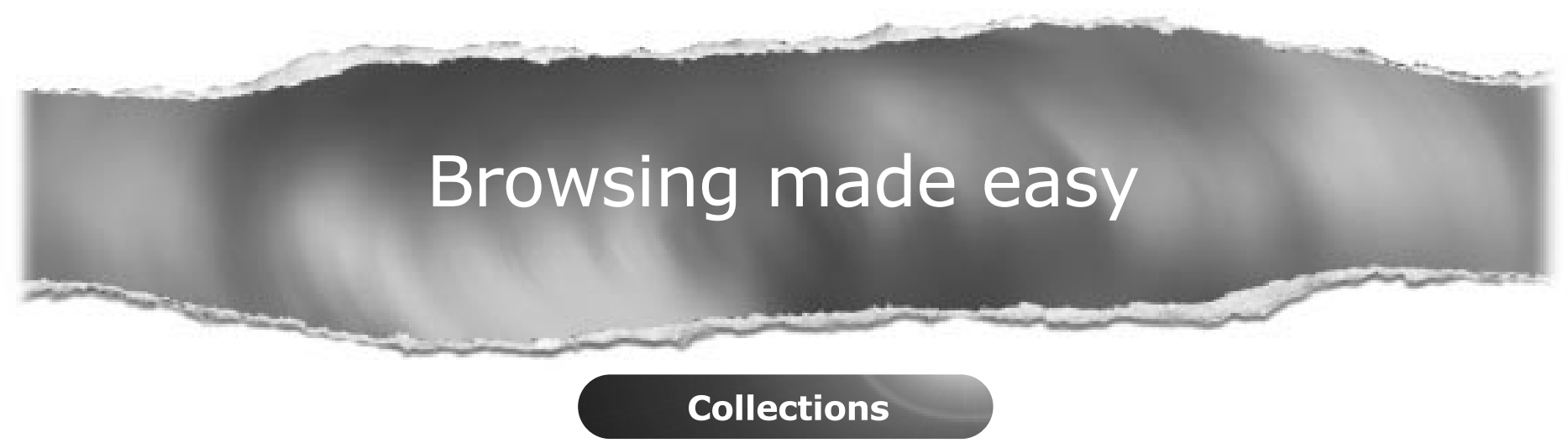

With a single click Collections allows you to find all articles that have been published in your chosen subject. Select from over 200 clinical and non-clinical topic collections and/or cross search other specialist journals, the BMJ and Cochrane Reviews

www.jech.com 